\title{
TRMT10A Mutation in a Child with Diabetes, Short Stature, Microcephaly and Hypoplastic Kidneys
}

\author{
(D) Eve Stern'1, (D) Asaf Vivante², (D) Ortal Barel33, (D) Yael Levy-Shraga1 \\ ${ }^{1}$ The Edmond and Lily Safra Children's Hospital, Sheba Medical Center, Unit of Pediatric Endocrinology and Diabetes, Tel-Hashomer; Tel-Aviv \\ University, The Sackler Faculty of Medicine, Tel-Aviv, Israel \\ 2The Edmond and Lily Safra Children's Hospital, Sheba Medical Center, Department of Pediatrics B and Pediatric Nephrology, Tel-Hashomer; Tel- \\ Aviv University, The Sackler Faculty of Medicine, Tel-Aviv, Israel \\ 3Sheba Cancer Research Center, The Genomic Unit, Tel-Hashomer; Tel-Aviv University, The Sackler Faculty of Medicine, Tel-Aviv, Israel
}

\section{What is already known on this topic?}

Over 40 different genetic subtypes of monogenic diabetes have been identified to date. TRMT10A mutations cause a distinct syndrome that includes abnormal glucose homeostasis, intellectual disability, short stature and microcephaly.

\section{What this study adds?}

Our report expands the phenotypic description of this syndrome. We report for the first time hypoplastic kidneys and inadequate response to growth hormone stimulation tests in a girl with this syndrome. Making a specific molecular diagnosis helps to predict the clinical course and enable genetic counseling, as well as personalized treatment.

\begin{abstract}
A new syndrome of diabetes, short stature, microcephaly and intellectual disability has been described in association with mutations in the tRNA methyltransferase 10 homologue A (TRMT10A) gene. We report a patient who presented with fasting hyperglycemia, a raised hemoglobin A1 c and positive islet cell autoantibodies. Additional clinical features included intellectual disability, hypoplastic kidneys and short stature. In view of the syndromic features coexistant with diabetes, genetic evaluation was carried out, revealing a homozygous mutation in the TRMT10A gene (c.616G > A, p.G206R). The case highlights the importance of genetic evaluation of patients with diabetes with atypical features that can further progress our understanding of the pathophysiology of the rarer subtypes of diabetes.
\end{abstract}

Keywords: Monogenic diabetes, short stature, microcephaly, hypoplastic kidneys

\section{Introduction}

Monogenic diabetes is uncommon, accounting for approximately $1 \%$ to $6 \%$ of pediatric diabetes patients $(1,2)$. The disease may be inherited within families as a dominant or recessive trait, and rarely through mitochondrial inheritance. It may also present as a spontaneous case due to a de novo mutation. Over 40 different genetic subtypes of monogenic diabetes have been identified to date, each having a typical phenotype and a specific pattern of inheritance. Maturity onset diabetes of the young (MODY) is by far the commonest type of monogenic diabetes.
All currently known subtypes of MODY are caused by dominant heterozygous mutations in genes important for the development or function of $\beta$-cells (3). Over the last few years, a number of forms of monogenic diabetes clinically and genetically distinct from MODY, have been identified.

In 2013, a new autosomal recessive syndrome, including short stature, microcephaly, intellectual disability and diabetes mellitus, was described in association with mutations in the tRNA methyltransferase 10 homologue A (TRMT10A) gene (4). Since the first description, only a few case reports of this syndrome have been published $(5,6,7,8,9)$.
Address for Correspondence: Yael Levy-Shraga MD, The Edmond and Lily Safra Children's Hospital, Sheba Medical Center, Unit of Pediatric Endocrinology and Diabetes, Tel-Hashomer; Tel-Aviv University, The Sackler Faculty of Medicine, Tel-Aviv, Israel

Phone: +972-3-5305015 E-mail: yael.levy.shraga@gmail.com ORCID: orcid.org/0000-0002-8603-4230
Conflict of interest: None declared Received: 25.11 .2020 Accepted: 28.12.2020 
The aim of this case report is to describe a girl that presented with hyperglycemia and positive autoantibodies with a presumed diagnosis of type 1 diabetes. Identification of the genetic etiology of a TRMT10A mutation improved the understanding of the disease course and enabled personalized clinical care.

\section{Case Report}

An 11-year-old girl was referred to the emergency room in light of high fasting glucose of $153 \mathrm{mg} / \mathrm{dL}$ (normal values 70$100 \mathrm{mg} / \mathrm{dL}$ ) and a hemoglobin A1c (HbA1c) of $9.9 \%$ (normal values $3.8-6.4 \%$ ). The patient was born to Jewish parents of Uzbekistan descent; parents were distantly related. Two older siblings were healthy and there was no family history of diabetes or any other autoimmune condition. Pregnancy was notable for intrauterine growth retardation (IUGR) demonstrated from week 17 of pregnancy. Birth weight was 2190 grams at term with no perinatal complications. Developmental milestones were delayed and the patient had been diagnosed with attention deficit disorder in early childhood.

At the age of two years old following repeated urinary tract infections, an ultrasound scan revealed bilateral mildly hypoplastic kidneys. Consequently, she was under nephrology follow-up that showed stable renal growth and normal renal function.

At the age of 11 years, her height was $127.3 \mathrm{~cm}$ [-2.3 standard deviation (SD)], weight $33.5 \mathrm{~kg}(-0.5 \mathrm{SD})$, body mass index (BMI) $20.7 \mathrm{~kg} / \mathrm{m}^{2}(1.0 \mathrm{SD})$ and head circumference $49 \mathrm{~cm}$ $(-2.0 \mathrm{SD})$ (Figure 1). Growth velocity was $4.2 \mathrm{~cm} /$ year. Due to

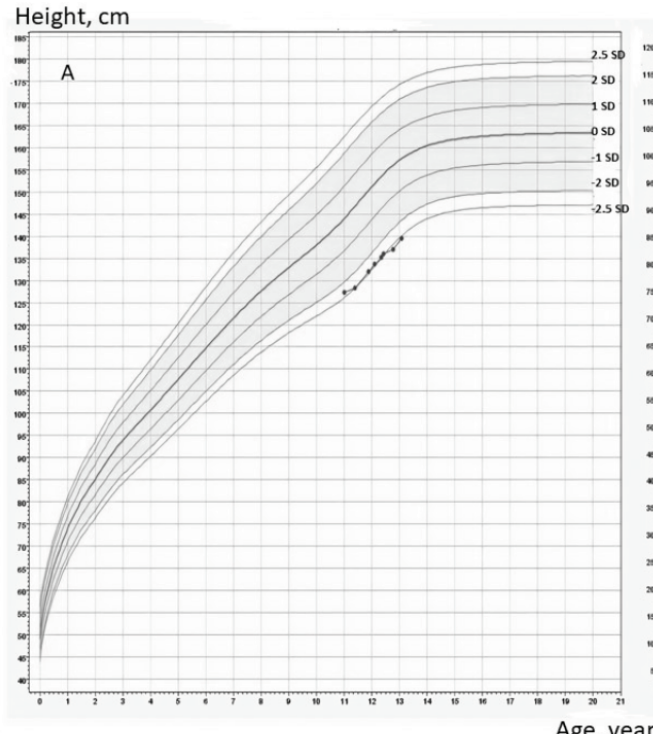

Age, years the short stature the patient was referred for endocrinological assessment. Laboratory investigations revealed fasting blood glucose of $110 \mathrm{mg} / \mathrm{dL}$ (normal values $70-100 \mathrm{mg} /$ $\mathrm{dL}$ ) and insulin-like growth factor $1168 \mathrm{ng} / \mathrm{mL}$ (normal range $118-448 \mathrm{ng} / \mathrm{mL}$ ). Her bone age determined using the Greulich-Pyle method was eight years and ten months at chronological age of ten years and nine months. On repeat laboratory investigations, fasting blood glucose was 153 $\mathrm{mg} / \mathrm{dL}$ and $\mathrm{HbA} 1 \mathrm{c} 9.9 \%$ (normal values 3.8-6.4\%). Medical history was negative for polydipsia, polyuria or significant weight loss. Subsequent laboratory examinations showed positive anti-islet cell antibodies $(76.9 \mathrm{IU} / \mathrm{mL}$, normal range 0-30) with weakly positive anti-GAD antibodies (7.4 IU/mL, normal range $0-5$ ). She was started on a low dose of long acting insulin with a working diagnosis of type 1 diabetes.

In view of the combination of IUGR, developmental delay, hypoplastic kidneys, short stature and diabetes, a genetic etiology was suspected. The presence of hypoplastic kidneys raised the suspicion for a diagnosis of MODY type 5 , which can include congenital renal malformations as a feature. Therefore, she was referred to the nephro-genetic clinic in our institute. On examination, dysmorphic features including microcephaly, narrow nasal bridge, retrognathia and beaked nose were observed. In addition, a large hyperpigmented skin lesion on her left thigh and bilateral fifth finger clinodactyly were noted. Microarray was reported as normal. Whole exome sequencing was carried out which revealed a homozygous missense mutation in the TRMT10A gene (NM_001134665, c.616G > A, p.G206R). This mutation has previously been reported (5). Both parents were found to be heterozygous for the mutation.

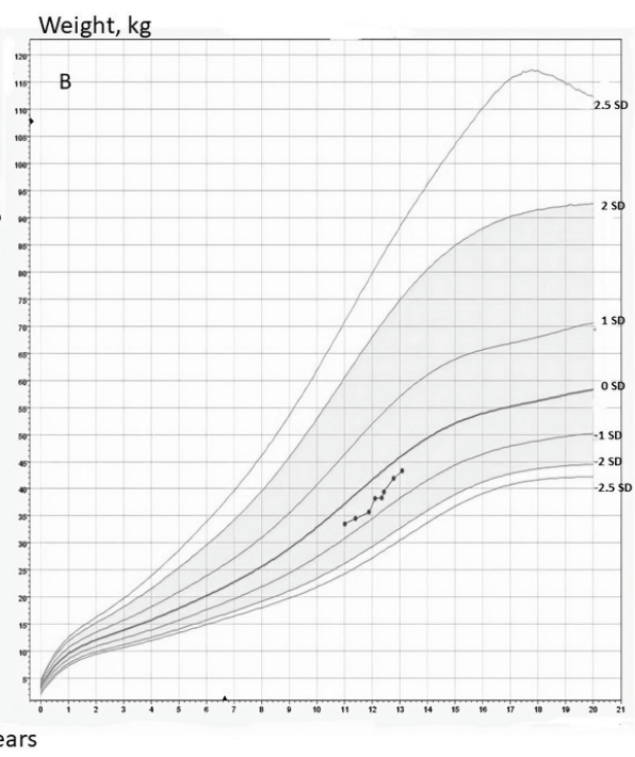

Figure 1. Height (A) and weight (B) curves of the patient 
Growth hormone stimulation tests were performed due to short stature, low growth velocity and delayed bone age. Peak growth hormone was $7.3 \mathrm{mcg} / \mathrm{L}$ after administration of clonidine and $1.8 \mathrm{mcg} / \mathrm{L}$ after administration of arginine, establishing a diagnosis of growth hormone deficiency. Magnetic resonance imaging (MRI) of the pituitary was reported as normal. Growth hormone replacement therapy was discussed with the family who decided against treatment.

In the subsequent months following diagnosis, glucose levels were well controlled with low doses of long acting insulin with no need for boluses of short acting insulin with meals. Subsequently short acting insulin was started with meals.

Two years following diagnosis, she was clinically well. Her height was $139.5 \mathrm{~cm}(-2.5 \mathrm{SD})$, weight $43.3 \mathrm{~kg}(-0.3 \mathrm{SD})$ and BMI $22.4 \mathrm{~kg} / \mathrm{m}^{2}(1.0 \mathrm{SD}$ ) (Figure 1). Pubertal status was Tanner stage 3 . The insulin requirement was 0.4 units $/ \mathrm{kg} /$ day. Glycemic control was good with fasting glucose $147 \mathrm{mg} /$ $\mathrm{dL}$ and HbA1c of $7 \%$. C-peptide level at the same time was still detectable at $2.47 \mathrm{ng} / \mathrm{mL}$ (normal range $0.9-7.1 \mathrm{ng} / \mathrm{mL}$ ). Monitoring glucose levels using the FreeStyle Libre flash glucose monitoring system demonstrated relatively stable glucose levels with no hypoglycemic events (Figure 2). Ophthalmic examination was normal with no evidence of retinopathy.

Informed consent from the parents of the patients was obtained for publication of the case.

\section{Discussion}

Here we present a case of monogenic diabetes due to TRMT10A mutation. The elevated fasting glucose and HbA1c of the patient met the criteria for a diagnosis of diabetes mellitus. Diabetes mellitus is a heterogeneous group of disorders with different genetic patterns and pathophysiological mechanisms. Type 1 diabetes is the most common type in the pediatric population and the patient had positive anti-islet cell antibodies. However, the low insulin requirements, detectable C-peptide levels and presence of extra pancreatic features (IUGR, developmental delay, hypoplastic kidneys, short stature) raised the suspicion of a genetic syndrome. The presence of hypoplastic kidneys was suspicious for a diagnosis of MODY type 5. However, no mutation in HNF1 $\beta$ was detected on whole exome sequencing. Type 2 diabetes is becoming an increasing problem in obese adolescents but the patient's BMI was in the normal range for her age.

TRMT10A mutation was first described in three siblings born to consanguineous parents of Moroccan descent, each with short stature and intellectual disability. They were diagnosed with diabetes between the ages of 14 and 22 years (4). All were negative for anti-GAD, islet cell and anti-insulin antibodies, in addition to having an HLA phenotype that did not confer risk of developing type 1 diabetes. Whole exome sequencing was carried out on one of the probands and one candidate mutation in chromosome 4 , a homozygous c.379G > A in exon 4 of TRMT10A was identified. This was predicted to replace an arginine residue with a premature stop codon at position 127 of the polypeptide chain. Both affected siblings were found to be homozygous for the

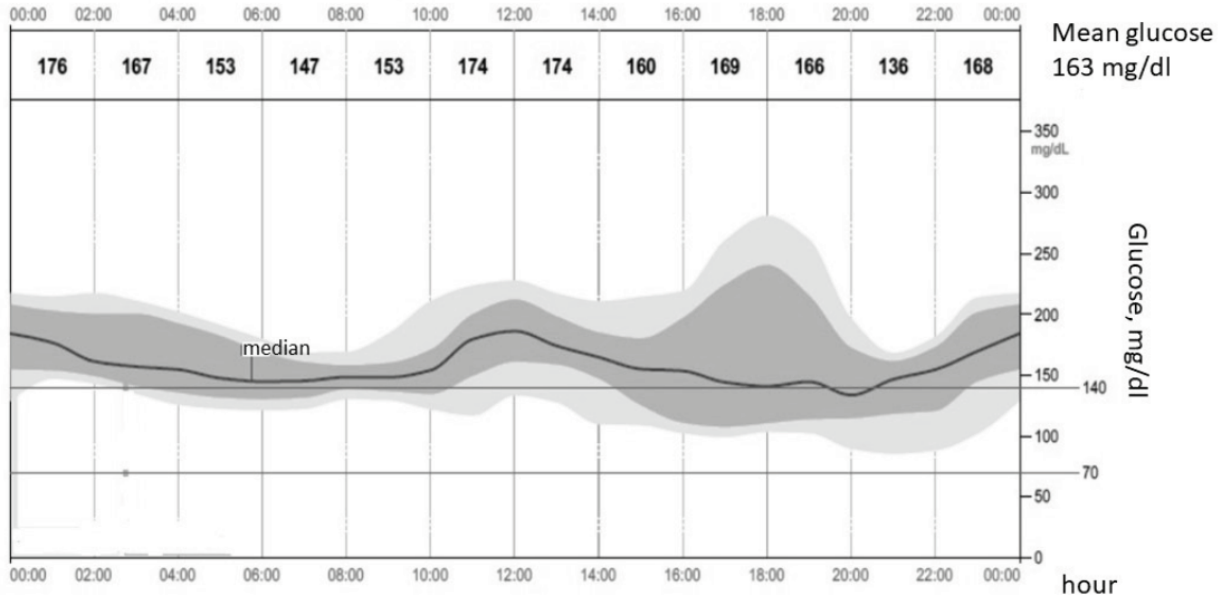

Figure 2. Averaged diurnal glucose levels within two weeks as measured by continuous glucose monitoring (Libre) two years after the diagnosis. At that time the daily insulin dose was 0.4 units/kg/day. The dark gray area represents the inter quantile range (IQR 25-75) of glucose levels and the black line the median

IQR: interquartile range 
mutation while the parents and an unaffected sibling were found to be heterozygous for the mutation.

Following this report, nine additional individuals from five different families were reported as having homozygous mutations, compound heterozygous or deletion in the same gene $(5,6,7,8,9)$. Similar to our patient, all reported patients exhibited intellectual disability and microcephaly (Table 1). In some patients the microcephaly presented at birth and resolved later and others had persistent microcephaly. Some patients had epilepsy and two patients had abnormal brain MRI findings (6).
Another main feature of the syndrome is abnormal glucose homeostasis. A variety of clinical presentations have been reported, including diabetes with or without ketosis, hyper insulinemic hypoglycemia, insulin resistance and postprandial hyperglycemia. The age at diabetes diagnosis ranged from nine to 28 years. Our patient was diagnosed with diabetes at the age of 11 years without ketoacidosis. Interestingly, she had positive islet cell antibodies, as was previously described in another patient (8). She had good glycemic control with relatively low insulin doses $(0.4$ units/kg/day) and detectable c-peptide two years after the diagnosis. This feature of well-preserved insulin secretion was previously reported in this syndrome $(4,7,8)$. Of note,

Table 1. Clinical characteristics of 13 patients from seven families with TRMT10A mutations

\begin{tabular}{|c|c|c|c|c|c|c|c|c|c|c|}
\hline Reference & No. & Gender & $\begin{array}{l}\text { TRMT10A } \\
\text { mutation }\end{array}$ & $\begin{array}{l}\text { Impaired glucose } \\
\text { metabolism }\end{array}$ & Treatment & Microcephaly & $\begin{array}{l}\text { Intellectual } \\
\text { disability }\end{array}$ & Epilepsy & $\begin{array}{l}\text { Short } \\
\text { stature }\end{array}$ & $\begin{array}{l}\text { Other } \\
\text { features }\end{array}$ \\
\hline \multirow[t]{3}{*}{$\begin{array}{l}\text { Igoillo- } \\
\text { Esteve et al } \\
\text { (4) } 2013\end{array}$} & 1 & F & $\begin{array}{l}\text { c.379 G > A; } \\
\text { p. Arg127Stop }\end{array}$ & Diabetes & Insulin & Yes & Yes & Yes & Yes & $\begin{array}{l}\text { Dysmorphic } \\
\text { features, } \\
\text { osteoporosis }\end{array}$ \\
\hline & 2 & F & $\begin{array}{l}\text { c. } 379 \mathrm{G}>\mathrm{A} \text {; } \\
\text { p. Arg127Stop }\end{array}$ & Diabetes & Insulin & Yes & Yes & NR & Yes & \\
\hline & 3 & M & $\begin{array}{l}\text { c. } 379 \mathrm{G}>\mathrm{A} \text {; } \\
\text { p. Arg127Stop }\end{array}$ & diabetes & Insulin & Yes & Yes & NR & Yes & \\
\hline \multirow[t]{3}{*}{$\begin{array}{l}\text { Gillis et al } \\
\text { (5) } 2014\end{array}$} & 4 & F & $\begin{array}{l}\text { c. } 616 \mathrm{G}>\mathrm{A}, \mathrm{p} . \\
\text { Gly206Arg }\end{array}$ & $\begin{array}{l}\text { Hyperinsulinaemic } \\
\text { hypoglycemia } \\
\text { and postprandial } \\
\text { hyperglycemia }\end{array}$ & Diet & Yes & Yes & Yes & Yes & $\begin{array}{l}\text { Delayed } \\
\text { puberty }\end{array}$ \\
\hline & 5 & M & $\begin{array}{l}\text { c. } 616 \mathrm{G}>\mathrm{A}, \mathrm{p} . \\
\text { Gly206Arg }\end{array}$ & As his sister & Diet & Yes & Yes & Yes & Yes & \\
\hline & 6 & M & $\begin{array}{l}\text { c. } 616 \mathrm{G}>\mathrm{A}, \mathrm{p} . \\
\text { Gly206Arg }\end{array}$ & As his sister & Diet & Yes & Yes & Yes & Yes & \\
\hline $\begin{array}{l}\text { Zung et al } \\
\text { (8) } 2015\end{array}$ & 7 & F & $4 q 23$ deletion & $\begin{array}{l}\text { Ketotic diabetes. } \\
\text { Positive islet cell } \\
\text { antibodies }\end{array}$ & Insulin & Yes & Yes & $\mathrm{Nr}$ & Yes & $\begin{array}{l}\text { Delayed } \\
\text { puberty }\end{array}$ \\
\hline \multirow[t]{2}{*}{$\begin{array}{l}\text { Yew et al (7) } \\
2016\end{array}$} & 8 & F & $\begin{array}{l}\text { c.79G > T; p. } \\
\text { Glu27Ter }\end{array}$ & $\begin{array}{l}\text { Diabetes, insulin } \\
\text { resistance }\end{array}$ & $\begin{array}{l}\text { Insulin, } \\
\text { metformin }\end{array}$ & Yes & Yes & Yes & No & $\begin{array}{l}\text { Buffalo } \\
\text { hump }\end{array}$ \\
\hline & 9 & M & $\begin{array}{l}\text { c. } 79 \mathrm{G}>\mathrm{T} ; \mathrm{p} . \\
\text { Glu27Ter }\end{array}$ & $\begin{array}{l}\text { Diabetes, insulin } \\
\text { resistance }\end{array}$ & Metformin & Yes & Yes & Yes & No & $\begin{array}{l}\text { Delayed } \\
\text { puberty }\end{array}$ \\
\hline \multirow[t]{2}{*}{$\begin{array}{l}\text { Narayanan } \\
\text { et al (6) } \\
2015\end{array}$} & 10 & F & $\begin{array}{l}\text { c. } 277 \mathrm{C}>\mathrm{T}, \mathrm{p} . \\
\text { Arg93* and } \\
\text { C. } 397 \mathrm{C}>\mathrm{T}, \mathrm{p} . \\
\text { Arg133* }\end{array}$ & No & - & Yes & Yes & NR & NR & $\begin{array}{l}\text { Dysmorphic } \\
\text { features, } \\
\text { abnormal } \\
\text { brain MRI }\end{array}$ \\
\hline & 11 & M & $\begin{array}{l}\text { c. } 277 \mathrm{C}>\mathrm{T}, \mathrm{p} . \\
\text { Arg } 93^{*} \text { and } \\
\text { C. } 397 \mathrm{C}>\mathrm{T}, \mathrm{p} . \\
\text { Arg } 133^{*}\end{array}$ & No & - & Yes & Yes & Yes & NR & $\begin{array}{l}\text { Pulmonary } \\
\text { infections, } \\
\text { abnormal } \\
\text { brain MRI }\end{array}$ \\
\hline $\begin{array}{l}\text { Lin et al (9) } \\
2020\end{array}$ & 12 & M & c. $496-1 \mathrm{G}>\mathrm{A}$ & Diabetes & Metformin & Yes & Yes & Yes & Yes & \\
\hline $\begin{array}{l}\text { Present } \\
\text { report }\end{array}$ & 13 & $\mathrm{~F}$ & $\begin{array}{l}\text { c. } 616 G>A, p . \\
\text { Gly206Arg }\end{array}$ & Diabetes & Insulin & Yes & Yes & No & Yes & $\begin{array}{l}\text { IUGR, } \\
\text { dysmorphic } \\
\text { features, } \\
\text { growth } \\
\text { hormone } \\
\text { deficiency, } \\
\text { hypoplastic } \\
\text { kidneys }\end{array}$ \\
\hline
\end{tabular}


our patient had the same mutation as the family described by Gillis et al (5). Both families originated from the same small and isolated Jewish community in Uzbekistan, yet the clinical phenotype differed between the two families. The three siblings had mainly hyperinsulinamic hypoglycemia (5), while our patient had diabetes with no documented hypoglycemic events.

Our novel finding is the hypoplastic kidneys and abnormal growth hormone stimulation tests, that were not previously described. Although short stature was previously described as part of this syndrome, this is the first time that growth hormone deficiency was diagnosed by stimulation tests. Additional features of the syndrome that were described in some of the patients included dysmorphic features and delayed puberty.

Transfer RNAs (tRNAs) are non-coding RNA molecules essential for protein synthesis (10). Across many species, tRNAs undergo complex post translational modifications including modification of tRNA nucleotide bases and sugars crucial for cellular function. Multiple enzymes have been identified that catalyze these posttranscriptional tRNA modification reactions. TRMT1OA encodes a protein that has tRNA $\mathrm{m}^{1} \mathrm{G}_{9}$ methyltransferase activity (7). The protein was first discovered in yeast and its homologues are widely conserved across eukarya and archaea (11). The functional characterization of human TRMT10A was recently studied (12). This nuclear protein is expressed in several tissues including the liver, kidney, spleen, lung and adipose tissue. The expression is enriched in the brain and pancreatic islet cells. This is consistent with the main features of the syndrome described: microcephaly, intellectual disability and abnormal glucose homeostasis. TRMT10A silencing has been shown to induce apoptosis, which suggests that mutations may negatively affect beta cell mass and the number of neurons in the developing brain (4).

\section{Conclusion}

In summary, our report expands the phenotypic description of this syndrome. This case demonstrates that genetic testing should be performed in those diabetic patients with preserved $\beta$-cell function over an extended period or with extra-pancreatic features. Further studies are needed to shed light on the pathogenesis resulting from TRMT10A inactivation.

\section{Ethics}

Informed Consent: Informed consent from the parents of the patients was obtained for publication of the case.

\section{Authorship Contributions}

Surgical and Medical Practices: Eve Stern, Asaf Vivante, Yael Levy-Shraga, Concept: Eve Stern, Asaf Vivante, Yael Levy-Shraga, Design: Eve Stern, Yael Levy-Shraga, Data Collection or Processing: Eve Stern, Ortal Barel, Yael LevyShraga, Analysis or Interpretation: Eve Stern, Asaf Vivante, Ortal Barel, Yael Levy-Shraga, Literature Search: Eve Stern, Asaf Vivante, Ortal Barel, Yael Levy-Shraga, Writing: Eve Stern, Asaf Vivante, Ortal Barel, Yael Levy-Shraga.

Financial Disclosure: The authors declared that this study received no financial support.

\section{References}

1. Delvecchio M, Mozzillo E, Salzano G, Iafusco D, Frontino G, Patera PI, Rabbone I, Cherubini V, Grasso V, Tinto N, Giglio S, Contreas G, Di Paola R, Salina A, Cauvin V, Tumini S, d'Annunzio G, Iughetti L, Mantovani V, Maltoni G, Toni S, Marigliano M, Barbetti F; Diabetes Study Group of the Italian Society of Pediatric Endocrinology and Diabetes (ISPED). Monogenic Diabetes Accounts for $6.3 \%$ of Cases Referred to 15 Italian Pediatric Diabetes Centers During 2007 to 2012. J Clin Endocrinol Metab 2017;102:1826-1834.

2. Shepherd M, Shields B, Hammersley S, Hudson M, McDonald TJ, Colclough K, Oram RA, Knight B, Hyde C, Cox J, Mallam K, Moudiotis C, Smith R, Fraser B, Robertson S, Greene S, Ellard S, Pearson ER, Hattersley AT; UNITED Team. Systematic Population Screening, Using Biomarkers and Genetic Testing, Identifies $2.5 \%$ of the U.K. Pediatric Diabetes Population With Monogenic Diabetes. Diabetes Care 2016;39:1879-1888. Epub 2016 Jun 6

3. Hattersley AT, Greeley SAW, Polak M, Rubio-Cabezas O, Njølstad PR, Mlynarski W, Castano L, Carlsson A, Raile K, Chi DV, Ellard S, Craig ME. ISPAD Clinical Practice Consensus Guidelines 2018: The diagnosis and management of monogenic diabetes in children and adolescents. Pediatr Diabetes 2018;19(Suppl 27):47-63.

4. Igoillo-Esteve M, Genin A, Lambert N, Désir J, Pirson I, Abdulkarim B, Simonis N, Drielsma A, Marselli L, Marchetti P, Vanderhaeghen P, Eizirik DL, Wuyts W, Julier C, Chakera AJ, Ellard S, Hattersley AT, Abramowicz M, Cnop M. tRNA methyltransferase homolog gene TRMT 10A mutation in young onset diabetes and primary microcephaly in humans. PLoS Genet 2013;9:e1003888. Epub 2013 Oct 31

5. Gillis D, Krishnamohan A, Yaacov B, Shaag A, Jackman JE, Elpeleg O. TRMT10A dysfunction is associated with abnormalities in glucose homeostasis, short stature and microcephaly. J Med Genet 2014;51:581. 586. Epub 2014 Jul 22

6. Narayanan M, Ramsey K, Grebe T, Schrauwen I, Szelinger S, Huentelman M, Craig D, Narayanan V; C4RCD Research Group. Case Report: Compound heterozygous nonsense mutations in TRMT10A are associated with microcephaly, delayed development, and periventricular white matter hyperintensities. F1000Res 2015;4:912.

7. Yew TW, McCreight L, Colclough K, Ellard S, Pearson ER. tRNA methyltransferase homologue gene TRMT10A mutation in young adultonset diabetes with intellectual disability, microcephaly and epilepsy. Diabet Med 2016;33:21-25

8. Zung A, Kori M, Burundukov E, Ben-Yosef T, Tatoor Y, Granot E. Homozygous deletion of TRMT10A as part of a contiguous gene deletion in a syndrome of failure to thrive, delayed puberty, intellectual disability and diabetes mellitus. Am J Med Genet A 2015;167:31673173. Epub 2015 Aug 22

Peer-review: Externally peer-reviewed. 
9. Lin $\mathrm{H}$, Zhou X, Chen X, Huang K, Wu W, Fu J, Li Y, Polychronakos C, Dong GP. tRNA methyltransferase 10 homologue A (TRMT10A) mutation in a Chinese patient with diabetes, insulin resistance, intellectual deficiency and microcephaly. BMJ Open Diabetes Res Care 2020;8:e001601.

10. Cosentino C, Toivonen S, Diaz Villamil E, Atta M, Ravanat JL, Demine S, Schiavo AA, Pachera N, Deglasse JP, Jonas JC, Balboa D, Otonkoski T, Pearson ER, Marchetti P, Eizirik DL, Cnop M, Igoillo-Esteve M. Pancreatic $\beta$-cell tRNA hypomethylation and fragmentation link
TRMT10A deficiency with diabetes. Nucleic Acids Res 2018;46:1030210318.

11. Jackman JE, Montange RK, Malik HS, Phizicky EM. Identification of the yeast gene encoding the tRNA M1G methyltransferase responsible for modification at position 9. RNA 2003;9:574-585.

12. Vilardo E, Amman F, Toth U, Kotter A, Helm M, Rossmanith W. Functional characterization of the human tRNA methyltransferases TRMT10A and TRMT10B. Nucleic Acids Res 2020;48:6157-6169. 